\title{
Agricultural restructuring in central and eastern Europe: implications for competitiveness and rural development
}

\author{
Alexander H. Sarris \\ University of Athens, Athens, Greece
}

\section{Tomáš Doucha}

Research Institute of Agricultural Economics, Prague, Czech Republic

\author{
Erik Mathijs \\ Katholieke Universiteit Leuven, Leuven, Belgium
}

Received April 1999

\section{Summary}

This paper considers whether the dual production structure now in place in central and eastern European countries (CEECs) is efficient and stable in the medium term. The large, recently emerged corporate and co-operative farm structures may not be stable because of conflicts inherent in co-operative production under current ownership structures. Such units use high levels of capital and purchased inputs, and relative price changes for production factors may threaten their survival without subsidies. The few large individual private operators that have emerged may soon face restructuring problems, as they have been relying on cheap capital at prices that do not reflect current replacement costs. New, younger, relatively small-scale farmers appear to have major and as yet unexploited production potential. Although representing only a small share of the many family farms, they are nevertheless numerous enough to create a viable 'middle class' of commercially oriented, private farmers. Although this group currently faces severe technological and financial constraints, the emergence of medium-sized, individually owned and operated farm units is the most viable option for the future in CEECs.

Keywords: farm restructuring, agricultural competitiveness, Central and Eastern Europe

JEL Classification: Q12, Q15, P00

\section{Introduction}

Whereas agricultural production in most central and eastern European countries (CEECs) is recovering from its post-transition decline, restructuring of production units is still in a state of flux. Farm restructuring has followed a 
dual path. Almost all state and collective farms have been downsized and reorganised. Some were transformed into producer co-operatives - an organisational form close to the original collective - whereas others have been converted into limited liability and joint stock companies or broken up into family farms or partnerships (Csaki and Lerman, 1997; Swinnen et al., 1997). The early expectation that land and other farm asset privatisation would stimulate the creation of many commercial family farms, similar to those prevalent in Western countries, has not been realised. What are the problems inherent in the creation of viable commercial family farm units in the CEECs, and are the structures that are currently in place efficient and likely to be stable in the medium term? This paper attempts to explore these questions and provide some tentative answers.

The issue of farm production structures is important for international competitiveness as well as for rural development. Efficient factor use and comparative advantage may be related to various farm production structures. Hence, integration of CEECs with Western Europe and the rest of the world may affect the economies of those countries differently depending on the ability of their farm structures to adapt and compete internationally. Rural development depends on viable sources of incomes for rural residents and agriculture normally provides the backbone of most rural economies. Hence, the viability of alternative agricultural production structures has direct implications for the welfare of rural areas in the CEECs.

Political-economy considerations were paramount in dictating the choice of the privatisation strategies in CEECs (Swinnen, 1997a). However, restructuring of agriculture is also determined by other factors. Mathijs and Swinnen (1998) have attempted to explain the degree of break-up of large-scale agricultural production units into individually operated farms, by reference to factors that affect the difference between the expected incomes of collective and individual farming, net of 'exit costs', namely the real and transactions costs involved in leaving a collective farm, plus the investment costs needed to start or enlarge a new private farm. They postulate that economies of scale and high labour productivity in collective farms discourage decollectivisation; that low product prices and high market risks also contribute to lower decollectivisation; and that restitution of collective farms to outsiders (such as former owners), the complexity of regulations governing implementation of privatisation and the transaction costs related to withdrawal of assets from collectives are important factors in delaying decollectivisation.

These studies rely on aggregate measures and considerations. Progress towards further understanding the process of structural adjustment in the agricultural sector of CEECs can come by better exploration of microeconomic considerations and the individual incentives faced by potential producers. Hypotheses derived from household decision models and testing based on micro-survey data are a natural extension of the earlier more macro-based analyses. In this paper, some tentative results from such recent work will be illustrated. 
In Section 2, we review the current literature concerning privatisation and land reform in the CEECs. Section 3 examines the evolution of production structures in CEECs since 1989, and in Section 4 we explore issues of efficiency for the new commercial farms. Section 5 discusses the structure of small-scale family farms on the basis of some recent farm household surveys. Section 6 presents some problems and issues in the development of small-scale private farms in CEECs. The final section presents some overall conclusions.

\section{Privatisation and land reform in the CEECs}

Table 1 shows that the process of agricultural land privatisation has been rather rapid. Whereas in 1989, the last year before the onset of transition, the share of agricultural land in private ownership was rather low, with privately owned land not exceeding 14 per cent in most CEECs (except in Poland and Slovenia), by 1995 more than 80 per cent of agricultural land was under private ownership in most CEECs. Even in Bulgaria, which had the lowest percentage of agricultural land under private ownership in 1995 (59 per cent), political changes since 1997 have accelerated the pace of land privatisation and restitution to former owners. Despite different speeds of land privatisation in different countries, which could be conditioned by political events and other country specific factors, most agricultural land in CEECs is now under private ownership.

Table 1. Share of agricultural land in private ownership (percentage of total agricultural land)

\begin{tabular}{lccc}
\hline & 1989 & 1993 & 1995 \\
\hline Albania & 3 & 90 & 96 \\
Bulgaria & 14 & 42 & 59 \\
Czech Republic & - & 65 & 81 \\
East Germany & 70 & - & 90 \\
Hungary & 13 & 50 & 90 \\
Poland & 76 & 76 & 77 \\
Romania & 14 & 70 & 80 \\
Slovakia & - & 54 & 90 \\
Slovenia & 83 & 85 & 86 \\
\hline
\end{tabular}

Source: Beckmann and Hagedorn (1997) and Macours and Swinnen (1997).

Collective farm land was privatised mostly by restitution, whereas privatisation of state farm land followed more mixed methods, with leasing and sales the dominant pattern (see Swinnen, 1997c). Many former owners have received agricultural land in historical boundaries, wherever this was possible, or property rights on land of comparable size and quality. Whereas land was mostly restored to former owners, non-land assets were distributed to both former owners and active members of collective farms and other entities 
(Swinnen and Mathijs, 1997). Land privatisation has not necessarily led to full transfer of property rights to the new private owners. Restrictions apply in most CEECs.

Swinnen (1997b) suggests that three major political-economy factors have conditioned these privatisation policy choices. First, assets that were still legally privately owned when reforms began in 1989 have been restored in all CEECs. This aspect largely conditioned the restitution of land, as well as the different treatment of land and non-land farm assets, as most of the latter, although initially brought into the collectives from private owners, were gradually replaced and acquired under collective ownership and hence were without clear individual private ownership.

The second factor was the ethnicity or nationality of former owners. Foreign landowners have not had land restored to them, an issue that has created problems, for instance, in the context of some CEECs' accession to the EU (e.g. Slovenia and Poland). On the other hand, the existence of large domestic ethnic constituencies that were not formerly landowners conditioned the choice of privatisation policies that gave larger shares of non-land farm assets, as in Bulgaria.

Third, the pre-collectivisation land ownership distribution has conditioned the trade-off and conflict between historical justice and social equity. In cases where former land ownership was egalitarian, as, for instance, in Bulgaria, restitution of land promoted both historical justice as well as social equity. Where the former land distribution was unequal, however, the two objectives were conflicting, as in Albania and Romania, and the choice was more influenced by the political balance during the early phase of transition.

The significant proportion of land under private ownership, however, is not matched by similar share of land operated by individual private farmers. In several CEECs, agricultural production is still dominated by large-scale production organisations such as producer co-operatives, joint stock companies, limited liability companies, partnerships and large individual farms. Many new landowners lease their land to the large-scale successor organisations of the collective and state farms.

\section{Evolution of production organisation in CEEC agriculture}

Two distinctive features of farm organisation have emerged in CEEC agriculture. The first is that much agricultural land is still operated by collectives or state farms, regardless of the degree of private land ownership. The second feature is that within privately operated farms a considerable duality has emerged, with a few large private farms dominating the picture, whereas a large number of smaller farms or plots account for a small amount of agricultural land and production.

Table 2 shows that, in the Czech Republic, whereas the share of land under state farms had declined to negligible proportions by 1997, the share of cooperatives' land had declined much less. By 1997 an estimated 38.7 per cent 
Table 2. Shares of agricultural land in the Czech Republic operated by different types of farm organisations, 1989-1997

\begin{tabular}{|c|c|c|c|c|c|c|}
\hline & 1989 & 1991 & 1993 & 1994 & 1995 & 1997 \\
\hline State farm & 25.4 & 25.6 & 12.9 & 2.8 & 1.2 & 0.5 \\
\hline Collective farm & 61.0 & 60.7 & - & - & - & - \\
\hline Co-operative & - & - & 49.4 & 47.7 & 42.8 & 38.7 \\
\hline Company ${ }^{1}$ & - & - & 14.6 & 20.5 & 25.0 & 23.5 \\
\hline Partnership & - & - & - & 0.3 & 0.3 & - \\
\hline $\begin{array}{l}\text { Sole } \\
\text { proprietorship }\end{array}$ & 0.3 & 3.3 & 13.4 & 20.4 & 22.3 & 25.1 \\
\hline Other $^{2}$ & 13.3 & 10.5 & 9.8 & 8.3 & 8.3 & 12.2 \\
\hline Total & 100.0 & 100.0 & 100.0 & 100.0 & 100.0 & 100.0 \\
\hline
\end{tabular}

${ }^{1,2}$ The class 'company' includes limited liability companies, the class 'other' includes joint stock companies, and other legal forms.

Source: Ratinger and Rabinowicz (1997) for 1989-1995; RIAE, Prague, for 1997 estimations.

of agricultural land was farmed by co-operatives, and this share, although falling over time, was still fairly large compared with that of privately owned agricultural land. The share of land operated by various types of companies as well as individual farmers and sole proprietorships has increased considerably. Table 2 excludes small holdings and hobby farms of less than 3 ha. The Research Institute of Agricultural Economics in Prague estimates that these small farms account for about 300,000 ha or less than 10 per cent of total agricultural land (personal communication).

Beckmann and Hagedorn (1997) show that the pattern in East Germany is strikingly similar to that of the Czech Republic, although German reunification has presumably created a different environment from that in the other CEECs. A large area of land is still farmed under co-operative organisation, partnerships or by commercial companies, and at the same time the share of sole proprietorships has been increasing.

Table 3 presents similar figures for Bulgaria. Despite the privatisation of land, a fairly large share of agricultural area is farmed by co-operatives. Similar patterns, albeit less marked, are documented for Hungary (Mathijs and Mészáros, 1997; Debatisse, 1999) and Romania (Sarris and Gavrilescu, 1997).

The overall picture indicates that despite extensive privatisation, there is still a substantial amount of land operated under co-operative organisation, and also a significant share operated by so-called commercial companies or enterprises (joint stock or limited liability). In some countries, these are just the renamed former state farms (Romania), whereas in other countries they include large private corporate farms (Bulgaria, Czech Republic). These are to be distinguished from individual farms or sole proprietorships in terms of the accounting methods used. However, the distinction is not sharp, as there are many so-called individual farms that are even larger than farms operated by 'companies' (for instance, in Bulgaria). 
Table 3. Pre-reform and post-reform agricultural structures in Bulgaria; shares of arable and total land

\begin{tabular}{|c|c|c|c|c|c|}
\hline & \multicolumn{2}{|c|}{$\begin{array}{l}1985 \text { share of }(\%) \\
\text { arable land }\end{array}$} & \multicolumn{3}{|c|}{1996 share of $(\%)$} \\
\hline & & & Arable land & Pastures & $\begin{array}{l}\text { Total agricultural } \\
\text { land }\end{array}$ \\
\hline $\begin{array}{l}\text { Agro-industrial complexes } \\
\text { (APKs) }\end{array}$ & 80.7 & State farms & 5.7 & 70.1 & 21.1 \\
\hline \multicolumn{6}{|l|}{ of which } \\
\hline $\begin{array}{l}\text { labour agricultural } \\
\text { co-operatives (TKZs) }\end{array}$ & 58.3 & Co-operatives & 42.4 & 13.6 & 35.5 \\
\hline state agricultural farms & 8.8 & & & & \\
\hline $\begin{array}{l}\text { machine and tractor } \\
\text { stations }\end{array}$ & 0.0 & & & & \\
\hline brigades & 13.6 & & & & \\
\hline $\begin{array}{l}\text { Other agricultural } \\
\text { organisations }\end{array}$ & 6.2 & & & & \\
\hline Private plots & 13.1 & $\begin{array}{l}\text { Individual farms } \\
\text { and farming } \\
\text { companies }\end{array}$ & 51.9 & 16.3 & 43.4 \\
\hline Total & 100.0 & & 100.0 & 100.0 & 100.0 \\
\hline
\end{tabular}

Source: European Commission (1998).

Although the legal status is one distinguishing feature, what matters for performance and efficiency is the way the production units operate. Here we can distinguish among three main types of organisations. First, corporate-type organisations are managed under the supervision of a board of directors (private or public). Farms of this type have limited liability up to the extent of assets of the enterprise. Privatised former state farms, and also some newly organised large private commercial farms, normally operate under such a structure. Second, we have co-operative organisations, where again the management operates under the formal or informal supervision of a board, which in this case is composed of members of the co-operative who own some assets of the co-operative and/or provide other inputs such as labour. Again, liability is usually limited to the assets of the co-operative, namely, what the members chose to bring into the co-operative production unit. Finally, there are individual farms, namely, sole proprietorships, where it is the individual farmer who makes all the decisions without supervision of a board. Such individual farms can be large or small, and have unlimited liability.

The striking feature of post-reform agriculture within the CEECs is that within the privately and individually operated farms, an extreme duality has emerged. In other words, there seem to be a few very large individual farms operating alongside large numbers of very small farms. Table 4 illustrates 
Table 4. Size distribution of individual farms in Bulgaria in 1996

\begin{tabular}{lrllll}
\hline $\begin{array}{l}\text { Groups by } \\
\text { farmed area (ha) }\end{array}$ & $\begin{array}{l}\text { Number } \\
\text { of farms }\end{array}$ & $\begin{array}{l}\text { Share of group } \\
\text { in total (\%) }\end{array}$ & $\begin{array}{l}\text { Farmed land } \\
(000 \mathrm{ha})\end{array}$ & $\begin{array}{l}\text { Average size } \\
\text { (ha) }\end{array}$ & $\begin{array}{l}\text { Share of farmed } \\
\text { land in total (\%) }\end{array}$ \\
\hline up to 0.2 & 915217 & 51.5 & 83.1 & 0.09 & 3.1 \\
$0.21-0.5$ & 363564 & 20.5 & 118.4 & 0.33 & 4.4 \\
$0.51-1.0$ & 256442 & 14.4 & 180.5 & 0.70 & 6.7 \\
$1.1-2.0$ & 156473 & 8.8 & 214.6 & 1.37 & 8.0 \\
$2.1-5.0$ & 68474 & 3.9 & 205.1 & 3.00 & 7.7 \\
$5.1-10.0$ & 13446 & 0.8 & 90.3 & 6.72 & 3.4 \\
over 10.0 & 3506 & 0.2 & 1783.2 & 508.60 & 66.7 \\
Total & 1777122 & 100.0 & 2675.3 & 1.51 & 100.0 \\
\hline
\end{tabular}

Source: European Commission (1998).

this with the size distribution of individual farms in Bulgaria in 1996: out of almost 1.8 million individual farms, only 3506 - or less than 0.2 per centoperated more than 10 ha of land. These larger farms, however, had an average size of 509 ha, and together occupied 67 per cent of the total land cultivated by individual farms. At the other end of the distribution, there were almost 1.3 million farms ( 72 per cent of all farms), each with less than 0.5 ha and accounting for only 7.2 per cent of all cultivated land. In the same year there were 364 state farms, each operating on average 3573 ha, and 3126 co-operatives, each operating on average 700 ha. Thus 85 per cent of all cultivated land was operated by only 7000 large farm units (companies, co-operatives and large individual farms). These constituted less than 0.4 per cent of all farming units in the country.

Table 5 presents the size distribution of 'organisations with accounting' and individual farms in Hungary for 1994. The situation is similar to that of Bulgaria. Less than 0.2 per cent of the farm organisations (public, co-operative and private) operate 84 per cent of the land, whereas among individual farms, 77 per cent of the smallest individual farms, with land smaller than $0.5 \mathrm{ha}$, operate on less than 4 per cent of the agricultural land. However, as in Bulgaria, there is a small number of individual farms (7200 of those with land larger than $10 \mathrm{ha}$ ), which have an average size of 24 ha and operate 3.6 per cent of the total land but 20 per cent of all land under individual farms.

The number and the size distribution of farms with less than 3 ha in the Czech Republic is not known, although it has been estimated that in total they account for about 300,000 ha of cultivated land. However, estimates of the size distribution of farms larger than 3 ha ('commercial farms') in the Czech Republic in 1997 (Table 6) tell a similar story. There are about 27,000 individual commercial farms that cultivate about 23 per cent of the total cultivated land. Other larger-scale 'business' or corporate farms number almost 3000 and cultivate 69 per cent of all land. Even among the so-called physical entities, there is considerable inequality. Among the 
Table 5. Size distribution of farm production units in Hungary in 1994

\begin{tabular}{|c|c|c|c|c|c|}
\hline $\begin{array}{l}\text { Farm size } \\
\text { (productive } \\
\text { land, ha) }\end{array}$ & Number & $\begin{array}{l}\text { Share in total } \\
\text { numbers }(\%)\end{array}$ & $\begin{array}{l}\text { Productive } \\
\text { land (000 ha) }\end{array}$ & $\begin{array}{l}\text { Average size } \\
\text { (ha) }\end{array}$ & $\begin{array}{l}\text { Share in total } \\
\text { land }(\%)\end{array}$ \\
\hline \multicolumn{6}{|c|}{ Organisations with accounting } \\
\hline Below 1000 & 1360 & 0.09 & 447 & 328.7 & 8.12 \\
\hline $1000-5000$ & 1106 & 0.07 & 2472 & 2235.1 & 44.93 \\
\hline Above 5000 & 106 & 0.01 & 1697 & 16009.4 & 30.84 \\
\hline Total & 2572 & 0.16 & 4616 & 1794.7 & 83.89 \\
\hline \multicolumn{6}{|l|}{ Individual farms } \\
\hline $0.00-0.19$ & 806,000 & 51.61 & 94.8 & 0.12 & 1.72 \\
\hline $0.20-0.49$ & 404,500 & 25.90 & 121.7 & 0.30 & 2.21 \\
\hline $0.50-0.99$ & 180,200 & 11.54 & 124.1 & 0.69 & 2.26 \\
\hline $1.00-1.99$ & 96,400 & 6.17 & 128.8 & 1.34 & 2.34 \\
\hline $2.00-4.99$ & 51,100 & 3.27 & 153.3 & 3.00 & 2.79 \\
\hline $5.00-9.99$ & 13,600 & 0.87 & 91.1 & 6.70 & 1.66 \\
\hline Above 10.00 & 7200 & 0.46 & 172.6 & 23.97 & 3.14 \\
\hline Total & $1,559,000$ & 99.84 & 886.4 & 0.57 & 16.11 \\
\hline Total all groups & $1,561,572$ & 100.00 & 5502.4 & 3.52 & 100.00 \\
\hline
\end{tabular}

Source: Mathijs and Mészáros (1997).

24,710 farms classified as physical entities, 16,000 are smaller than 4 European Size Units (ESU), ${ }^{1}$ average about 10 ha in size, and employ on average less than one permanent worker. At the other end of the spectrum, there are 1736 very large individual farms, with average size larger than 16 ESU, average area of 1269 ha, and employing on average 9.4 permanent workers.

In Romania, as Table 7 illustrates, there is considerable duality between 'formal organisations', namely commercial companies, and individual households, with the former accounting for only 0.5 per cent of farm production units but cultivating about 40 per cent of the land. However, amongst the numerous individual farms the distribution is more even than that observed in Bulgaria, Hungary and the Czech Republic, with the largest 10 per cent of individual farms cultivating about 30 per cent of the land.

The situation in Slovakia is also dualistic. According to Kabat and Hagedorn (1997) there were only 8931 surveyed farm production units in 1994 (household plots, which must be very numerous, were excluded). Of those, 86 per cent (7572) were unregistered individual farmers and the rest were various types of companies, co-operatives and state enterprises. Individual private farmers accounted for only 4 per cent of the agricultural land of all 
Table 6. Size distribution of commercial farms in the Czech Republic in 1997

\begin{tabular}{lrlcrc}
\hline & Number & $\begin{array}{l}\text { Share in number } \\
\text { of commercial } \\
\text { farms (\%) }\end{array}$ & $\begin{array}{l}\text { Total } \\
\text { agricultural } \\
\text { land (000 ha) }\end{array}$ & $\begin{array}{l}\text { Average } \\
\text { size (ha) }\end{array}$ & $\begin{array}{l}\text { Share in } \\
\text { agricultural } \\
\text { land (\%) }\end{array}$ \\
\hline Physical entities $>3$ ha & 24,710 & 89.4 & 889.6 & 36 & 23.2 \\
Business companies & 1869 & 6.8 & 1244.8 & 666 & 32.5 \\
$\quad$ Limited companies & 1349 & 4.9 & 826.9 & 613 & 21.6 \\
$\quad$ Joint stock companies & 484 & 1.8 & 403.2 & 833 & 10.5 \\
Co-operatives & 1011 & 3.7 & 1363.8 & 1349 & 35.6 \\
State farms & 22 & 0.1 & 19.0 & 864 & 0.5 \\
Other commercial & 30 & 0.1 & 10.0 & 333 & 0.3 \\
Total commercial & 27,642 & 100.0 & 3527.2 & 127.6 & 92.2 \\
Individual small farms & & & 300.0 & & 7.8 \\
$<3$ ha & & & 3827.2 & & 100.0 \\
Total & & & & &
\end{tabular}

Source: estimates of the RIAE, Prague.

these entities, with co-operatives and state farms accounting for 52 per cent and 40 per cent, respectively. Among the few individual farmers, 76 per cent had less than 10 ha, but they farmed less than 15 per cent of the land. The pattern is similar to that in the Czech Republic.

The above figures suggest that the emerging farm structures in most CEECs are dualistic, both when examined on a corporate individual basis and when only individual farms are considered.

Table 7. Size distribution of agricultural production units in Romania in 1995

\begin{tabular}{lrlcrc}
\hline & Number & $\begin{array}{l}\text { Share in } \\
\text { number }(\%)\end{array}$ & $\begin{array}{l}\text { Total land } \\
(000 \text { ha })\end{array}$ & $\begin{array}{l}\text { Average } \\
\text { size (ha) }\end{array}$ & $\begin{array}{l}\text { Share in } \\
\text { agricultural } \\
\text { land (\%) }\end{array}$ \\
\hline Commercial companies & 550 & 0.02 & 2051 & 3729.1 & 15.3 \\
Agricultural societies & 3973 & 0.11 & 1733 & 436.2 & 12.9 \\
Family associations & 15,915 & 0.44 & 1596 & 100.3 & 11.9 \\
Individual households & $3,597,383$ & 99.44 & 8052 & 2.2 & 59.9 \\
Total & $3,617,821$ & 100.00 & 13,432 & 3.7 & 100.0 \\
Among individual & & & & & \\
households & $1,007,267$ & 28 & 483.1 & 0.48 & 6 \\
$\quad<1$ ha & $1,546,875$ & 43 & 2737.7 & 1.77 & 34 \\
1-3 ha & 683,503 & 19 & 2415.6 & 3.53 & 30 \\
3-5 ha & 359,738 & 10 & 2415.6 & 6.71 & 30 \\
$>10$ ha & & & & & \\
\hline
\end{tabular}

Source: Romania, Ministry of Agriculture and Food (1997) and Sarris and Gavrilescu (1997). 


\section{Productive efficiency of the emerging commercial farms in CEECs}

What has been the impact of these dualistic paths of farm restructuring on efficiency and competitiveness? Studies using aggregated country data to illustrate the relationship between farm restructuring and efficiency show how output has recovered fast in countries where the emergence of family farms has been strong, such as Albania and Romania, whereas it has decreased in countries where family farms account for less than half the agricultural land, such as the Czech Republic, Hungary and Slovakia (Mathijs and Swinnen, 1998). However, farm restructuring is also related to technology and the change in the agricultural labour force. In the Czech Republic, Hungary and Slovakia - countries with a relatively high degree of mechanisation - there was a large flow of labour out of agriculture, such that labour productivity increased. In countries with a relatively low degree of mechanisation, such as Albania and Romania, labour flowed into agriculture. Nevertheless, Macours and Swinnen (1997) have demonstrated that the establishment of family farms has had a positive impact on total factor productivity in all CEECs.

Studies in East Asia using more disaggregated data generally show a positive impact on efficiency of reform towards a family farm based system (e.g. McMillan et al. (1989), for China; Pingali and Xuan (1992), for Vietnam). The evidence for Russia and other countries of the Former Soviet Union (FSU) is still inconclusive, mainly because of the high variability in efficiency among farms (Johnson et al., 1994). Nevertheless, Lerman (1998) suggests positive effects of the shift to individual farming by observing higher income levels in family farms. However, further reform to boost sustainable efficiency gains seems to be absent, both in China and in FSU countries, as property rights to land are ill-defined, managerial efficiency does not change and there are few investments in new technologies (Choe, 1996; Lerman, 1998; Sotnikov, 1998).

\subsection{Theoretical considerations}

To be competitive and efficient, a farm needs to use the best practice not only with respect to technology, but also with respect to its internal organisation and market actions. In a perfectly functioning market environment, an inefficient farm will be outcompeted and go bankrupt. Reform measures such as the liberalisation of prices and the abolition of subsidies increase the competitive pressures in agriculture and push farms to the efficient frontier or drive them out of business. As a result, farm managers have an incentive to purchase the right amounts of inputs, as they now face hard budget contraints, and to apply those inputs in their best use. Inefficient farms can thus survive only in the presence of market imperfections, which can have many sources. ${ }^{2}$ Whereas various studies have emphasised human capital, farm management practices and the economic environment (market structure and government)

2 A notable example is the X-inefficiency of monopolistic firms (Leibenstein, 1966). 
as important sources of inefficiency, ${ }^{3}$ we limit our discussion to the inefficiency that arises when a farm does not address the moral hazard problems as a result of the costs of organisation (Masten et al., 1991) and those that are related to the costs of using the market (Coase, 1937).

A first set of moral hazard problems and the transaction costs that relate to them may occur inside the farm and can be referred to as the governance problem of the farm. Moral hazard within the farm is a consequence of the difficulty of linking effort to output in team production (Alchian and Demsetz, 1972). As a result, many have considered the relatively small-scale family farm as a superior governance structure, when compared with production co-operatives or factory-style farms (Pollak, 1985; Schmitt, 1991). But, as the difficulty of measuring output and effort results from the biological — and thus uncertain - character of the agricultural production process, innovations mitigating the effects of nature (such as greenhouses and stables) reduce the superiority of family farms as institutions for minimising transaction costs (Allen and Lueck, 1998). Once management and ownership of the farm are separated, its performance will be subject to the same forces that govern non-agricultural businesses, such as ownership and control. ${ }^{4}$

A second set of moral hazard problems are due to the transaction costs of using the market. First, such transaction costs may be due to the temporal specificity of successive production stages in the vertical product chain. When this temporal specificity is high, such as in arable crop farming, the transaction cost minimising solution is to integrate the successive production stages. Family farms will thus be more efficient in arable crop farming, considering also the limited scope for labour specialisation because of the low frequency of production cycles per year (arable crops, cow-calf and sowpiglet farms). In sectors where this temporal specificity is lower and there are more cycles per year (dairy, greenhouses, broilers, feedlot cattle and hogs), large-scale corporate farms will be more efficient because of the gains of labour specialisation and pecuniary scale economies (such as capital provision) (Deininger, 1995; Allen and Lueck, 1998). Second, market transaction costs can be the result of imperfections in product and factor markets. Particularly during transition, many markets are ill-developed, such as the land and credit market, whereas others are characterised by monopsonistic market power. An example of the latter are the delayed payments some farmers receive from the buyers of their products (Gow and Swinnen, 1998).

To conclude, inefficiency may arise as a result of the moral hazard problems of sub-optimal organisational and market actions. On the basis of these considerations, predictions can be made with respect to how further restructuring will take place and explanations can be provided for why restructuring often seemed to be slow or unable to increase efficiency. Thus, as large-scale farms cannot solve the moral hazard problems in arable farming, whereas 
large-scale livestock units capture the gains to labour specialisation and pecuniary scale economies, it can be predicted that CEEC agriculture will evolve to a family farm based arable sector, whereas corporate farms will specialise in certain forms of livestock (dairy, intensive poultry, pig and cattle fattening), similar to developments in North America and Western Europe.

\subsection{Empirical evidence}

We now draw from studies that have compared levels of technical efficiency of different farm types and sizes, to illustrate some of the above issues. A farm is technically efficient if it produces on the boundary of the production possibility set, i.e. it maximises output with given inputs and given the available technology. This boundary or frontier is identified by the best practice observed in a certain set of farms. Although technical efficiency is only one component of competitiveness or economic efficiency, it is a necessary condition for being competitive and it is much easier to calculate. In other words, farms that are not even technically efficient will not be economically efficient either. Studies using data envelopment analysis to calculate technical efficiency can also decompose the total level of technical efficiency into pure technical efficiency and scale efficiency by varying the assumptions on production technology. To calculate total technical efficiency, a constant returns to scale (CRS) frontier is assumed, whereas for pure technical efficiency, the production technology is assumed to display variable returns to scale (VRS). Scale efficiency is then the ratio between total and pure technical efficiency (Färe et al., 1985).

A first set of studies that relate technical efficiency to farm structures was carried out using aggregated East German data (Mathijs and Swinnen, 1997; Thiele and Brodersen, 1997). Table 8 summarises the results by Mathijs and Swinnen (1997), who used averages for certain categories of farms. The table shows the efficiency of each farm category as a percentage of the efficiency achieved by the most efficient farm group in the sample. Partnerships were the most efficient structure in both crop and livestock production, and corporate farms (co-operatives and companies) improved their situation relative to family farms over the 4 years of the study (1992-1995). Family farms were too small on average, as was reflected by their low levels of scale efficiency, and thus consistently displayed lower levels of total technical efficiency. Only under VRS conditions were family farms more efficient than corporate farms at the beginning of transition. Mathijs and Swinnen (1997) further suggested the existence of a U-shaped average cost curve in crop farming and an L-shaped average cost curve in livestock production. This not only confirms the widely found result that there are no economies of scale beyond a minimal threshold size (Hallam, 1991), but also supports Allen and Lueck's (1998) qualification of this general result by suggesting that in crop farming large-scale farms are less efficient than smaller-scale farms.

Results of a 1996 analysis of a cross-section of Czech farms by Mathijs et al. (1998) are provided in Table 9. As efficiency scores are calculated here for 
Table 8. Technical efficiency of East German farms by product specialisation and organisational form, 1991-1992 and 1994-1995

\begin{tabular}{|c|c|c|c|c|}
\hline & \multicolumn{2}{|l|}{ Crops } & \multicolumn{2}{|l|}{ Livestock } \\
\hline & $1991-1992$ & $1994-1995$ & $1991-1992$ & 1994-1995 \\
\hline \multicolumn{5}{|c|}{ Total technical efficiency (CRS frontier) } \\
\hline Family farms & 82.2 & 80.5 & 87.2 & 82.0 \\
\hline Partnerships & 100.0 & 96.8 & 99.9 & 99.8 \\
\hline Corporate farms & 93.3 & 92.7 & 87.2 & 94.8 \\
\hline \multicolumn{5}{|c|}{ Pure technical efficiency (VRS frontier) } \\
\hline Family farms & 100.0 & 97.8 & 100.0 & 93.4 \\
\hline Partnerships & 100.0 & 96.9 & 100.0 & 100.0 \\
\hline Corporate farms & 96.9 & 100.0 & 87.2 & 94.9 \\
\hline \multicolumn{5}{|c|}{ Scale efficiency (ratio of total to pure technical efficiency) } \\
\hline Family farms & 82.2 & 82.3 & 87.2 & 87.8 \\
\hline Partnerships & 100.0 & 99.9 & 99.9 & 99.8 \\
\hline Corporate farms & 96.3 & 92.7 & 100.0 & 99.9 \\
\hline
\end{tabular}

Source: Mathijs and Swinnen (1997).

individual farms instead of for average farms, the scores which were corrected for regional effects are also retained. Only the corrected scores can be used for proper interpretation. The results show that Czech family farms are more efficient than co-operatives and companies in crop production and livestock fattening. The technical efficiency advantage of family farms is pure, that is, it is not due to scale effects. The only exceptions are mixed farms with crops and dairy cows, where companies are the most efficient organisation and family farms the least efficient. One reason for this discrepancy between dairy cows on the one hand and beef cattle and pigs on the other hand may be that technological innovation in Czech cattle and pig farms has not yet resulted in a high degree of labour specialisation, that is, they are still raising their own calves and piglets. A final result of the study is that farm size has no significant impact on technical efficiency.

The most recent analyses concern Hungarian farms (Banse et al., 1998; Hughes, 1999; Mathijs and Vranken, 1999). Hughes (1999) used 1997 FADN data to calculate total factor productivities (TFP) by sector and by farm structure. In crop production, the TFP scores for family farms (107 for family farms smaller than 15 ha, and 121 for larger family farms) were considerably higher than those for co-operatives (66) and particularly companies (41). In the livestock sector, medium-sized family farms (15-30 ha) were the most productive farms, followed by co-operatives (110), large family farms (>30 ha), companies (95) and small family farms (92). The analysis 
Table 9. Technical efficiency of Czech farms by product specialisation and organisational form, $1996^{1}$

\begin{tabular}{|c|c|c|c|c|c|c|}
\hline & \multicolumn{2}{|c|}{$\begin{array}{l}\text { Total technical efficiency } \\
\text { (CRS frontier) }\end{array}$} & \multicolumn{2}{|c|}{$\begin{array}{l}\text { Pure technical efficiency } \\
\text { (VRS frontier) }\end{array}$} & \multicolumn{2}{|c|}{$\begin{array}{l}\text { Scale efficiency } \\
\text { (ratio) }\end{array}$} \\
\hline & $\mathrm{U}$ & $\mathrm{C}$ & $\mathrm{U}$ & $\mathrm{C}$ & $\mathrm{U}$ & $\mathrm{C}$ \\
\hline \multicolumn{7}{|l|}{ Crops } \\
\hline Family farms & 67.0 & 67.0 & 84.0 & 84.0 & 78.1 & 78.1 \\
\hline Co-operatives & 71.5 & 52.5 & 84.7 & 79.7 & 85.2 & 72.5 \\
\hline Companies & 59.4 & 26.3 & 66.9 & 42.5 & 89.5 & 70.5 \\
\hline \multicolumn{7}{|c|}{ Livestock fattening } \\
\hline Family farms & 68.8 & 82.1 & 84.7 & 91.7 & 80.3 & 82.1 \\
\hline Co-operatives & 52.5 & 41.4 & 56.4 & 56.9 & 94.7 & 81.1 \\
\hline Companies & 53.5 & 45.0 & 61.4 & 69.0 & 89.9 & 76.3 \\
\hline \multicolumn{7}{|c|}{ Crops and livestock fattening } \\
\hline Family farms & 61.3 & 77.1 & 87.0 & 98.8 & 69.8 & 78.8 \\
\hline Co-operatives & 76.5 & 51.3 & 80.6 & 59.9 & 93.4 & 82.0 \\
\hline Companies & 59.9 & 51.5 & 61.5 & 58.7 & 95.4 & 82.9 \\
\hline \multicolumn{7}{|l|}{ Crops and dairy } \\
\hline Family farms & 72.5 & 64.5 & 90.9 & 98.8 & 79.1 & 71.5 \\
\hline Co-operatives & 67.3 & 69.6 & 68.3 & 87.2 & 98.5 & 81.9 \\
\hline Companies & 66.0 & 78.8 & 66.6 & 82.8 & 98.9 & 86.6 \\
\hline
\end{tabular}

${ }^{1}$ Both uncorrected (U) and corrected (C) efficiency scores are displayed. The corrections came from a Tobit analysis of the original efficiency values with fixed effects for organisational form per production specialisation and for region. The reference was family farms in crop farming in region 'fodder growing areas'. The other areas are 'maize', 'sugarbeet', 'cereals' and 'potatoes'.

Source: Mathijs et al. (1998).

by Hughes also shows that smaller farms are more productive, especially in crop production, somewhat contrary to the Czech Republic where size had no effect. Although he points to the system of external services (e.g. harvesting) to private farmers that existed long before the reform began in 1989, these results are consistent with the predictions of Allen and Lueck (1998).

In their study of Hungarian crop farms based on 1998 survey data, Mathijs and Vranken (1999) confirm the findings of Hughes (1999) concerning the higher efficiency of family farms. However, they provide much more detailed results concerning the impact of governance on efficiency. More specifically, they show the following:

(i) de novo farms, i.e. farms established by a group of farmers who left the state or collective farm, or of former owners to whom assets were restored, are 
more efficient than privatised and transformed successor farms. This is consistent with findings for industrial firms (Konings, 1997).

(ii) Manager-controlled farms, i.e. farms owned or dominated by the manager, are more efficient than worker-controlled farms (production cooperatives). This is also consistent with the findings that within the population of insider-controlled firms, manager-owned firms perform better than worker-owned firms (Jones, 1997).

(iii) Farm enterprises that have a high share of outside owners (e.g. absentee landowners) are less efficient than farms with a high share of insiders. Contrary to industrial sectors where outside ownership increases access to capital, in agriculture outside owners often contribute to the farm's equity in the form of land but the enterprise cannot use that land as collateral.

The evidence on inefficiency as a result of inefficient market actions is much scarcer. For example, Thiele and Brodersen (1997) show that mixed farms are more efficient than specialised crop farms. Mathijs and Vranken (1999) suggest that some farm enterprises that are partly integrated with up- and downstream firms are less efficient. This is probably due to the way in which the original collective was transformed. In these cases, it is very likely that 'good' assets were transferred to the up- or downstream firm, whereas 'bad' assets were left in the transformed collective, a process that was possible in the initial stages of transformation in Hungary in 1992. Unlike Hungary, in the Czech Republic the settlement of old debts was delayed until 1999. However, many farm managers did not wait until then and created a new company to which they transferred the 'good' assets, a process named 'the second wave of transformation'. This explains why other farm enterprises are more efficient.

Mathijs and Vranken (1999) further showed that family farms that sold their products under contract were more efficient than farms that did not. This finding provides strong support for the suggestion by Gow and Swinnen (1998) that innovative contracts offered to farmers by food processors increase producer prices, ensure prompt payment and induce farmers to invest in new technologies.

\section{Some evidence from the small-scale individual farm sectors of CEECs}

The evidence summarised above suggests that, on the whole, individually operated farms are more efficient than co-operative farms and large commercial companies that succeeded the state farms. This implies that individually operated farms are the most likely to expand in number and importance in CEEC agriculture. However, all the above analyses were carried out using data from the largest among the various types of individual private farms. In other words, the sample included mostly data from the small number of very large individual private farms that, as indicated in Section 3, are a very small share of all private farms but account for the bulk of production or area cultivated. 
Two questions arise in this context. First, can agriculture be viable in the future in any CEEC with only a small number of large farms, individual or corporate? Second, if the answer to the first question is no, then where will the new private 'commercial farmers' come from, and what are the constraints facing them in starting or expanding their operations?

The current duality of agricultural production structures in the CEECs, and especially the duality amongst individual private farms, coupled with the similar level of efficiency of individual and corporate farms and the apparent lack of economies of scale for commercial farms suggest that there is room for more commercial individual farms within CEECs. In other words, their current number is low.

The issue then arises of how the numerous small farms are going to add to the number of commercial farms. In other words, how can some small farms be transformed into larger, more commercial farms? To answer this question requires information about the nature of these small farmers and an assessment of their constraints. In what follows, we look more closely into these issues using some recent farm household surveys. We utilise the results of two recent national surveys of individual private farms in Romania (one carried out 1994 and analysed by Sarris and Gavrilescu (1997), and the other in 1996 and reported by Romania, Ministry of Agriculture and Food (1997)). We also utilise early results from a recent and as yet unpublished national survey of Bulgarian farm households carried out in 1998 by two of the authors (Mathijs and Sarris), and some results from recent farm censuses in Slovenia. In all surveys, most of the surveyed farms were small. For instance, in the 1996 Romanian survey, 90 per cent of the farms were smaller than 5 ha and accounted for 70 per cent of the surveyed cultivated land. In the 1998 Bulgarian survey, 95 per cent of the surveyed farms were smaller than 5 ha. The results from similar surveys in other CEECs in which the authors are involved are not yet available. It nevertheless appears that the observations from the first surveys might be generalisable, and in any case they form hypotheses to be verified in other CEECs.

The first observation prompted by the surveys is that the owners and operators of small farms tend to be older people. In Romania, the 1994 survey showed the average age of those surveyed (heads of households) was 56 years, with only 35.2 per cent below 50. In the 1996 survey, the average age of all household members older than 15 years old was 57 . In households composed only of agriculturally occupied persons (58 per cent of all households surveyed), the average age of adults (namely persons older than 15 years) was 61 . By contrast, the average age of adults in households with only nonagriculturally occupied persons (only 6 per cent of surveyed households), and in households with both agriculturally and non-agriculturally occupied people, was 46 years in both cases. Such households comprised 6 and 25 per cent of all farm households, respectively. Finally, 11 per cent of the households surveyed were non-active economically (pensioners, etc.) with average adult age of 71 . In the Bulgarian survey, the average age of the heads of the households surveyed was 62 . It thus seems that even in countries like 
Romania that have experienced an increase in rural population because of the hardships of transition, there are not many younger people among full-time farmers, and that the bulk of younger operators are part-timers.

A second observation is that despite the adverse age structure, many small farms seem to have potential for expansion. In the 1996 Romanian survey, for instance, an index of entrepreneurial behaviour of farm operators was designed by factor analysis. The index was highest for farmers below the age of 50, with farms larger than 2 ha. Many of these were part-time farmers. In Bulgaria, the 1998 survey showed that individual farmers operating larger areas were younger, better educated, and operated considerably more land than they owned (through renting), compared with the very small ones. For Slovenia, Table 10 shows the changes in farm structure between 1991 and 1997. Although the total area farmed by individual farmers, as well as their number, has declined, there has clearly been an expansion both in number and cultivated area of larger full-time and part-time farmers, and especially in the number and area of part-time farmers.

Third, we observe that the gradual expansion of the number of larger individual farmers is taking place despite the limitations imposed by incomplete land restitutions and rigid land market regulations. In most CEECs, agricultural land markets are very undeveloped, primarily because of the incompleteness of restitution, and legal restrictions on land sales. However, there seems to be considerable leasing out by absentee landowners, as well as renting by both co-operatives and other corporate farms, and by smaller individual farmers. In the Bulgarian survey, it is clear that most of the small landowners lease out most of the land they own, and the larger individual private farm operators rent most of the land they cultivate.

A fourth observation is that the majority of the small farmers surveyed produce mainly for themselves. For instance, in Romania in 1996, 51 per cent of farm households surveyed did not sell anything, especially those smaller than 2 ha. For most main products, over 90 per cent of households did not make any sales. On average, only 26 per cent of total household cash income came from agricultural sales. In Slovenia and for 1996, although households produced 76 per cent of all agricultural output, they accounted for only 59 per cent of all sales of agricultural products, the rest being accounted for by corporations (the successors of state farms). Households consumed 54 per cent of all products produced.

Fifth, we observe that, on the output and input markets, most small farmers are tied to larger farm units such as new co-operatives, former state farms and larger commercial private farms. For instance, in Slovenia, which has the most advanced small-scale private individual agriculture among CEECs, 70 per cent of all farm sales occur through new co-operatives or former state farms. In Romania, a significant share of sales occurs through state agencies. As very few small private farmers own farm equipment, they tend to rent services from co-operatives or larger farmers. In Bulgaria, 83 per cent of the individual farmers surveyed stated that they belonged to a co-operative, and in most cases the co-operative provided machinery services. This implies 
Table 10. Number of private farms in Slovenia in 1997, area farmed, and changes between 1991 and 1997 according to the distribution of farmed land and the proportion of time spent farming

\begin{tabular}{|c|c|c|c|c|c|c|c|c|c|c|}
\hline \multirow[t]{2}{*}{ Size (ha) } & \multicolumn{2}{|l|}{ Total } & \multicolumn{2}{|c|}{ Full time } & \multicolumn{2}{|l|}{ Part time } & \multicolumn{2}{|c|}{ Supplementary ${ }^{1}$} & \multicolumn{2}{|l|}{ Aged } \\
\hline & No. & ha & No. & ha & No. & ha & No. & ha & No. & ha \\
\hline Total & 90,613 & 433,142 & 13,849 & 102,736 & 25,288 & 143,477 & 41,781 & 156,722 & 9,696 & 30,209 \\
\hline$<2$ & 24,799 & 30,462 & 1,495 & 2,113 & 3,817 & 5,163 & 14,839 & 18,008 & 4,649 & 5,178 \\
\hline $2-5$ & 34,356 & 115,552 & 4,026 & 14,010 & 10,219 & 35,676 & 16,792 & 54,899 & 3,320 & 10,967 \\
\hline $5-10$ & 22,762 & 160,589 & 4,989 & 36,098 & 8,018 & 57,459 & 8,328 & 57,425 & 1,427 & 9,608 \\
\hline$>10$ & 8,696 & 126,539 & 3,339 & 50,515 & 3,234 & 45,179 & 1,822 & 26,390 & 300 & 4,456 \\
\hline \multicolumn{11}{|c|}{ Change 1991-1997 } \\
\hline Total & $-21,290$ & 58,399 & $-9,940$ & $-3,443$ & $-29,788$ & $-40,406$ & 19,549 & 98,677 & $-1,110$ & 3,577 \\
\hline$<2$ & $-24,217$ & $-25,825$ & $-5,874$ & $-6,548$ & $-19,328$ & $-22,071$ & 2,595 & 4,393 & $-1,609$ & $-1,599$ \\
\hline $2-5$ & $-6,121$ & $-21,979$ & $-4,297$ & $-15,184$ & $-11,015$ & $-36,541$ & 9,327 & 30,084 & -135 & -335 \\
\hline $5-10$ & 3,780 & 26,275 & $-1,584$ & $-11,857$ & $-1,232$ & $-7,092$ & 6,122 & 42,217 & 474 & 3,009 \\
\hline$>10$ & 5,268 & 79,928 & 1,815 & 30,146 & 1,787 & 25,298 & 1,505 & 21,983 & 160 & 2,502 \\
\hline
\end{tabular}

${ }^{1}$ Supplementary farms are essentially part-time ones by Western definitions.

Source: FAO (Food and Agriculture Organization) (1999). 
that small farmers are affected by what has been termed interlocking factor and output markets (for a survey of the literature, see Bell (1989)).

A final observation is that very few of the small farmers are investing, for lack of own money or any type of formal credit. In Romania, for instance, only 4 per cent of farmers surveyed bought any equipment in the previous year and only 24 per cent bought any livestock. In almost all cases, the money invested was own money. In the few cases where loans were obtained, most loans were from family associations or formal associations, with very small incidence of borrowing from formal financial institutions such as banks. In Bulgaria, whereas 19 per cent of farm households bought some livestock in the previous year, less than 1 per cent bought any equipment. Again, the bulk of the money was own money.

These remarks suggest that, although the majority of small-scale private farms in CEECs are operated by aged farmers, and for subsistence rather than commercial purposes and hence without much possibility or desire for expansion, there is nevertheless substantial scope for a considerable number of the smaller farmers to expand operations and become commercial. The issue is whether the environment facing these farmers is conducive to such an expansion.

\section{Issues in the emergence of smaller-scale individual private farmers in CEECs}

There are several areas where the current environment is constraining the expansion of those small farmers that have the potential to expand and become commercial. First, the current imperfections in agricultural land markets have led to substantial amounts of leasing and renting, but current landowners prefer to lease their land for short periods only (normally one or at most a few years) because of the overall uncertainty. This implies that those renting land are unwilling to make long-term investments in land improvements such as the application of phosphate fertilisers. Their interest will be to 'mine' the land to the maximum extent, which will lead to longterm deterioration of the productive potential of the resource and make the emergence of new farmers even more difficult. Thus, the development of agricultural land markets is a high priority.

A second major constraint is the technology awareness of small farmers. As is well known, the research and education system under the former regimes trained specialists for specific tasks within the large agro-industrial production units (Csaki, 1998). Many of the new landowners who live and work in rural areas were specialists in some agricultural task (e.g. mechanics or livestock specialists) and worked in collective farms, but did not have the management and overall technical expertise to run an integrated farm. Furthermore, the research system explored and disseminated technologies appropriate to large-scale farming and geared to the relative prices of the communist period, which were considerably different from those of the present. In particular, the prices of inputs such as fertilisers and machinery 
relative to labour were considerably lower than at present. Hence, the technologies researched were mostly intensive in capital and purchased inputs. Such techniques are for the most part uneconomic under current conditions, certainly for smaller-scale farms. There is no new system of research, however, into production systems geared to smaller-scale production and even if there were, the extension systems in most CEECs are very rudimentary and hence are not geared to training large numbers of small farmers.

A third major constraining factor involves capital, both start-up capital and working capital. With a shortage of internal resources, new large individual private farms have emerged on the basis of capital (assets) accumulated in the pre-reform period. This concerns many of the farms that were formed by former managers of co-operatives or other senior specialists, who managed to obtain a substantial portion of the more productive non-land assets of the former co-operatives or state farms through the process of privatisation. However, these assets are rather obsolete, tailored to large-scale production, and normally do not comply with new environmental standards. Again, it is expected that given the high current cost of capital replacement, many of these large-scale private farmers will face financing problems in the near future. Already this is evidenced by the fact that the governments of many CEECs have instituted credit subsidy programmes, which for the most part favour the large-scale private and corporate farms, but not the small ones.

The many small farmers who would like to expand lack access to formal capital both as working capital and for start-up purposes. The various credit schemes that have been instituted do not, for the most part, make any such credits or credit guarantees available to small farms. This implies that lack of credit may be forcing many small but potentially good commercial farmers into production structures that are less conducive to expansion and growth. Adapting the theoretical framework of Eswaran and Kotwal (1986), Tritten and Sarris (1998) find evidence in the 1998 Bulgarian survey data that credit constraints condition the choice of labour allocation and agricultural production regime among Bulgarian private farmers. Rizov et al. (1999) also find strong empirical evidence with the 1996 Romanian survey that the development of individual farming is severely hindered by capital constraints.

A final major constraint concerns the various conflicts that are inherent within the newly established co-operative or collective farms that control a significant portion of area farmed in most CEECs. There are three types of interest groups amongst these farm types. There are landowners, who may want to withdraw their restored land, but may judge that the services, rent and other benefits of having their land under co-operative cultivation are more advantageous than individual cultivation. Of course, they may also find that the transaction costs involved in withdrawal are very large. The owners of the various non-farm assets of the co-operatives constitute the second group, which could be partially overlapping with the land-owning group, but is mostly weighted towards former workers. The final group 
consists of the current managers and workers of such co-operatives. They may or may not be owners of land and assets. It is reasonable to hypothesise that the first group is mostly interested in land rents, the second in returns to nonland assets, and the third in wages or returns to labour. The inherent conflict between these three objectives may be the main reason for the eventual decline and dissolution of this type of production organisation. As these organisations, however, currently seem to account for several interlinked transactions with individual private small farmers (e.g. provision of machinery services, employment of some family labour, provision of seasonal credit), their future development will affect the opportunities and constraints facing small farmers.

It is not clear whether the new middle-level farmers will emerge primarily from the further deterioration of the large post-transition co-operative structures or from the many new, currently small and capital-constrained farms. This, however, does not matter. We suggest that the current dual structure is not viable in the medium run, in the context of an internationally competitive agricultural sector in the CEECs. Appropriate policies will have to be put in place to facilitate the smooth evolution towards more balanced and equitable farm structures.

\section{Concluding remarks}

The current situation facing CEEC agriculture is precarious. On the one hand, the large corporate and co-operative farm structures that have emerged from the process of restructuring may not be stable given the inherent conflicts in co-operative production under the current ownership structures. Such units use capital and purchased inputs intensively and, with the change in the relative prices of production factors, may soon find themselves unable to survive without subsidies, the cost of which can hardly be borne by the strained government budgets of most CEECs. On the other hand, the few large individual private operators that have emerged and currently dominate the individualistic farming sectors in CEECs may soon face restructuring problems, given that they have been using considerable amounts of cheap capital (land and non-land) at prices that do not reflect the current replacement costs.

It appears that a major and as yet unexploited potential in agricultural production exists among the group of new small-scale farmers who are younger and could be potentially viable. Although they constitute a small minority of the many small-scale family farms, they are nevertheless numerous enough to create a viable 'middle class' of commercially oriented private individualistic farmers. It appears, however, that this group, which maybe the best prospect for agriculture in the CEECs, is currently very constrained on most fronts, both technological and financial. Most CEEC governments still have, as their ideal for private agriculture, the notion of large-scale agricultural production units, albeit privately owned and operated (whether under corporate or individual management). Although such farms may be efficient in specific 
production activities, such as intensive livestock production, it is our opinion that this direction is not the most viable in the context of a post-transition steady state, particularly as most CEECs have a comparative advantage in crop production. We rather believe that the emergence of farm units that are middle sized, middle class (in income terms) and individualistic (in terms of ownership and operation) is the most viable option for the medium and long term in CEECs. A dualistic farm structure of the type that has emerged in the first 10 years after the fall of communism is neither efficient nor equitable. The challenge, therefore, for the CEEC governments is to adopt policies that will help to eliminate the polarising forces of the past few years, and that will promote farm structures that are more viable and equitable in the long term.

Concerning rural development, it is best promoted by developing adequatesized rural markets that generate adequate rural incomes, which can in turn support the rural location of private income-producing activities. Under the communist regimes, rural development was promoted by the deliberate location of industrial and other non-agricultural activities in rural areas, to provide alternative sources of incomes for rural populations. The transition has seen the demise of many of these non-agricultural production activities, and consequently much of the rural non-agricultural income base has been eroded. Coupled with the emerging duality in agricultural production, it is clear that, for most rural residents, rural incomes have suffered, and this is reflected in the massive exodus in most CEECs of younger people from rural areas, both to cities within the CEECs and to foreign countries. Although a government-led policy of locating production activities in rural areas is much more difficult to implement in a market economy, a viable and equitable agriculture can provide a first boost to rural incomes and help revive the rural economies. The same holds for the national economies as well, as in many CEECs agriculture is one of the few sectors with a clear comparative advantage based on natural conditions and geography. It is in this context that agricultural development is crucial for both rural development and aggregate economic development within CEECs. Current structures and policies, however, have polarised incomes and have led to rural stagnation. The challenge for the governments of the CEECs is to realise this link and institute policies to reverse the current trends.

\section{Acknowledgements}

The authors acknowledge the financial help of the European Union's Phare ACE programme, through which several research projects involving the authors have been conducted.

\section{References}

Alchian, A. A. and Demsetz, H. (1972). Production, information costs and economic organization. American Economic Review 62: 777-795.

Allen, D. W. and Lueck, D. (1998). The nature of the farm. Journal of Law and Economics 41: $343-386$. 
Banse, M., Bargel, T., Gorton, M., Hartell, J., Hughes, G., Kockler, J. and Muench, W. (1998). The evolution of competitiveness in Hungarian agriculture: from transition to accession. Paper presented at the seminar Competitiveness of Agricultural Enterprises and Farm Activities in Transition Countries, IAMO, Halle/Saale, Germany, 22-24 November 1998.

Beckmann, V. and Hagedorn, K. (1997). Decollectivisation and privatisation policies and resulting structural changes of agriculture in Eastern Germany. In J. F. M. Swinnen, A. Buckwell and E. Mathijs (eds), Agricultural Privatisation, Land Reform and Farm Restructuring in Central and Eastern Europe. Aldershot: Ashgate, 105-160.

Bell, C. (1989). Credit and interlinked transactions. In H. Chenery and T. N. Srinivasan (eds), Handbook of Development Economics, Vol. I. Amsterdam: North Holland.

Choe, C. (1996). Incentive to work versus disincentive to invest: the case of China's rural reform, 1979-1984. Journal of Comparative Economics 22: 242-266.

Coase, R. H. (1937). The nature of the firm. Economica 4: 386-405.

Csaki, C. (1998). Agricultural research in transforming Central and Eastern Europe. European Review of Agricultural Economics 25(3): 289-306.

Csaki, C. and Lerman, Z. (1997). Land reform and farm restructuring in East Central Europe and CIS in the 1990s: expectations and achievements in the first five years. European Review of Agricultural Economics 24: 428-452.

Debatisse, M. (1999). Hungary: a Successful Agriculture and Food Economy in Constant Search for Higher Competitiveness. World Bank, ECSSD Environmentally and Socially Sustainable Development, Working Paper 9. Washington, DC: World Bank.

Deininger, K. (1995). Collective agricultural production: a solution for transition economies? World Development 23: 1317-1334.

Eswaran, M. and Kotwal, A. (1986). Access to capital and agrarian production organisation. Economic Journal 86: 482-498.

European Commission (1998). Agricultural Situation and Prospects for Central and Eastern Europe. Bulgaria. Brussels: European Commission, DG VI.

FAO (Food and Agriculture Organization of the United Nations) (1999). Policy Options for Slovenia Agriculture in an EU Accession Environment: Main Report. Ministry of Agriculture, Food and Forestry, Slovenia; Rome, FAO.

Färe, R., Grosskopf, S. and Lovell, C. A. K. (1985). The Measurement of Efficiency in Production. Boston, MA: Kluwer-Nijhoff.

Gow, H. R. and Swinnen, J. F. M. (1998). Up- and downstream restructuring, foreign direct investment, and hold-up problems in agricultural transition. European Review of Agricultural Economics 25: 331-350.

Hallam, A. (1991). Economies of size and scale in agriculture: an interpretive review of empirical measurement. Review of Agricultural Economics 13: 155-171.

Hughes, G. (1999). Total Productivity of Emergent Farm Structures in Central and Eastern Europe. Report of Task 2 of the FAIR-project on Agricultural Implications of CEEC Accession to the EU. Wye: University of London.

Johnson, S. R., Bouzaher, A., Carriquiry, A., Jensen, H. and Lakshminarayan, P. G. (1994). Production efficiency and agricultural reform in Ukraine. American Journal of Agricultural Economics 76: 629-635.

Jones, D. C. (1997). The Determinants of Economic Performance in Transitional Economies. The Role of Ownership, Incentives and Restructuring. Helsinki: UNU World Institute for Development Economics Research. 
Kabat, L. and Hagedorn, K. (1997). Privatisation and decollectivisation policies and resulting structural changes of agriculture in Slovakia. In J. F. M. Swinnen, A. Buckwell and E. Mathijs (eds), Agricultural Privatisation, Land Reform and Farm Restructuring in Central and Eastern Europe. Aldershot: Ashgate, 229-280.

Kalirajan, K. P. (1990). On measuring economic efficiency. Journal of Applied Econometrics 5: $75-85$.

Konings, J. (1997). Firm growth and ownership in transition countries. Economics Letters 55: $413-418$.

Leibenstein, H. (1966). Allocative efficiency and X-efficiency. American Economic Review 56: $392-415$.

Lerman, Z. (1998). Does land reform matter? Some experiences from the former Soviet Union. European Review of Agricultural Economics 25: 307-330.

Macours, K. and Swinnen, J. F. M. (1997). Causes of Output Decline in Economic Transition: the Case of Central and Eastern European Agriculture. Policy Research Group Working Paper No. 11. Leuven: Department of Agricultural Economics, Katholieke Universiteit Leuven.

Masten, S., Meehan, J. and Snyder, E. (1991). The costs of organization. Journal of Law, Economics and Organization 7: 1-26.

Mathijs, E. and Mészáros, S. (1997). Privatisation and restructuring in Hungarian agriculture. In J. F. M. Swinnen, A. Buckwell and E. Mathijs (eds), Agricultural Privatisation, Land Reform and Farm Restructuring in Central and Eastern Europe. Aldershot: Ashgate, 161-188.

Mathijs, E. and Swinnen, J. F. M. (1997). Production Organization and Efficiency during Transition: the Case of East German Agriculture. Policy Research Group Working Paper No. 7. Leuven: Department of Agricultural Economics, Katholieke Universiteit Leuven.

Mathijs, E. and Swinnen, J. F. M. (1998). The economics of agricultural decollectivization in East Central Europe and the Former Soviet Union. Economic Development and Cultural Change 47(1): 1-26.

Mathijs, E. and Vranken, L. (1999). Farm efficiency and restructuring: evidence from Hungarian crop farms. Leuven: Department of Agricultural and Environmental Economics, Katholieke Universiteit Leuven.

Mathijs, E., Doucha, T., Dries, L. and Swinnen, J. F. M. (1998). Production efficiency and organization of Czech agriculture. Paper presented at the EAAE seminar on Nature, Evolution and Efficiency of Farm Structures in CEECs and FSU, Sofia, Bulgaria, 2930 May 1998.

McMillan, J., Whalley, J. and Lijing, Z. (1989). The impact of China's economic reforms on agricultural productivity growth. Journal of Political Economy 97: 781-807.

Pingali, P. L. and Xuan, V. T. (1992). Vietnam: decollectivization and rice productivity growth. Economic Development and Cultural Change 40: 697-718.

Pollak, R. A. (1985). A transaction cost approach to families and households. Journal of Economic Literature 23: 581-608.

Ratinger, T. and Rabinowicz, E. (1997). Changes in farming structures in the Czech Republic as a result of land reform and privatisation. In J. F. M. Swinnen, A. Buckwell and E. Mathijs (eds), Agricultural Privatisation, Land Reform and Farm Restructuring in Central and Eastern Europe. Aldershot: Ashgate, 63-104.

Romania, Ministry of Agriculture and Food (1997). Private agriculture in Romania: farm survey. Ministry of Agriculture and Food, European Commission, World Bank, joint survey. 
Rizov, M., Gow, H., Mathijs, E. and Swinnen, J. (1999). The development of individual farming in Romania. Leuven: Department of Agricultural and Environmental Economics, Katholieke Universiteit Leuven.

Sarris, A. H. and Gavrilescu, D. (1997). Restructuring of farms and agricultural systems in Romania. In J. F. M. Swinnen, A. Buckwell and E. Mathijs (eds), Agricultural Privatisation, Land Reform and Farm Restructuring in Central and Eastern Europe. Aldershot: Ashgate, 189-228.

Schmitt, G. (1991). Why is the agriculture of advanced western countries still organized by family farms? Will this continue to be so in the future? European Review of Agricultural Economics 18: 443-458.

Sotnikov, S. (1998). Evaluating the effects of price and trade liberalisation on the technical efficiency of agricultural production in a transition economy: the case of Russia. European Review of Agricultural Economics 25: 412-431.

Swinnen, J. F. M. (ed.) (1997a). Political Economy of Agrarian Reform in Central and Eastern Europe. Aldershot: Ashgate.

Swinnen, J. F. M. (1997b). The choice of privatization and decollectivization policies in Central and Eastern European agriculture: observations and political economy hypotheses. In J. F. M. Swinnen (ed.), Political Economy of Agrarian Reform in Central and Eastern Europe. Aldershot: Ashgate, 363-398.

Swinnen, J. F. M. (1997c). Agricultural reform in Central and Eastern Europe. In C. Eicher and J. Staatz (eds), Agricultural Development in the Third World, 3rd edn. Baltimore: Johns Hopkins University Press.

Swinnen, J. F. M. and Mathijs, E. (1997). Agricultural privatisation, land reform and farm restructuring in Central and Eastern Europe: a comparative analysis. In J. F. M. Swinnen, A. Buckwell and E. Mathijs (eds), Agricultural Privatisation, Land Reform and Farm Restructuring in Central and Eastern Europe. Aldershot: Ashgate, 333-373.

Swinnen, J. F. M., Buckwell, A. and Mathijs, E. (eds) (1997). Agricultural Privatisation, Land Reform and Farm Restructuring in Central and Eastern Europe. Aldershot: Ashgate.

Thiele, H. and Brodersen, C. M. (1997). Anwendung der nicht-parametrischen Data Envelopment Analysis auf die Effizienz landwirtschaftlicher Unternehmen in der Transformation Ostdeutschlands. Agrarwirtschaft 46: 407-416.

Tritten, C. and Sarris, A. (1998). Agrarian production organisation under transition to market economy in Bulgaria. Athens: Department of Economics, University of Athens.

Corresponding author: Alexander Sarris, Department of Economics, University of Athens, 8 Pesmazoglou Street, Athens, GR-10559, Greece. E-mail: asarris@hol.gr 
